Jurnal Indonesia Sosial Teknologi: p-ISSN: 2723 - 6609

e-ISSN : 2745-5254

Vol. 2, No. 10 Oktober 2021

\title{
PERANCANGAN SISTEM INFORMASI PEMESANAN MAKANAN BERBASIS WEB DI FOODCOURT RSKIA BANDUNG
}

\author{
Dinni Indriani ${ }^{1}$, Asep Saeful ${ }^{2}$, Ardi Taryanto ${ }^{3}$. \\ Politeknik Piksi Ganesha Bandung ${ }^{1,2,3}$ \\ Email: dinniindriani26@gmail.com ${ }^{1}$, asepsaefu1875@gmail.com ${ }^{2}$, \\ ardipiksi@yahoo.com³.
}

\begin{abstract}
Abstrak
Penelitian ini bertujuan untuk menganalisis, merancang dan membangun implementasi sistem informasi pemesanan makanan dengan studi kasus di Foodcourt RSKIA Bandung. Teknik pengumpulan data yang digunakan dengan cara melakukan kajian Pustaka, wawancara dan observasi. Metode pengembangan perangkat lunak yang digunakan adalah prototype. Dari penelitian yang telah dilakukan, terdapat faktor yang menghambat sistem informasi pemesanan makanan karena masih menggunakan cara manual menggunakan media kertas yang dirasakan kurang efektif dan efisien sehingga sering terdapat kesalahan pencatatan transaksi, data hilang, dan keterlambatan pelaporan. Oleh karena itu, dalam penelitian ini dibuat suatu perancangan sistem informasi pemesanan makanan menggunakan Unified Modelling Languange dan diimplementasikan dengan bahasa pemrograman PHP dengan framework Code Igniter serta My SQL sebagai database. Pengujian aplikasi menggunakan black box. Dengan adanya aplikasi ini diharapkan sebagai sarana pengolahan transaksi pemesanan makanan menjadi lebih efektif dan efesien.
\end{abstract}

Kata kunci: Sistem Informasi; Pemesanan Makanan; UML; Web.

\section{Abstract}

This study aimed to analyze, design and build the implementation of a food ordering information system with a case study at the food court RSKIA Bandung Data collection techniques used by conducting library studies, interviews and observations. The software development method used is a prototype. From the research that has been done, there are factors that hinder the food ordering information system because it still uses the manual method using paper media which is felt to be less effective and efficient so that there are often errors in recording transactions, missing data, and reporting delays. Therefore, in this study, a food ordering information system was designed using the Unified Modeling Language and implemented in the PHP programming language with the Code Igniter framework and My SQL as a database. Application testing using black box. With this application, it is hoped that the processing of food order transactions will be more effective and efficient.

Keywords: Information System, Food order, UML, Web 


\section{Pendahuluan}

Foodcourt adalah salah satu area yang biasanya berada di dalam area sebuah gedung atau bangunan yang mana terdapat fasilitas Tenant yang menyediakan berbagai macam makanan dan minuman dengan cara melayani diri sendiri untuk memesan makanan. Kesuksesan suatu usaha Foodcourt sangat dipengaruhi oleh kualitas penyajian makanan dan pelayanan yang diberikan oleh Foodcourt tersebut. Hal ini menjadi penting karena inti dari bisnis ini adalah penawaran campuran (hybrid) yaitu barang berupa makanan dan minuman serta jasa berupa layanan yang diberikan (RRZ, Hudiaman, Wicaksana, \& Listiyani, 2013).

Terdapat beberapa permasalahan pemesanan yang terjadi di foodcourt RSKIA diantaranya mencatat pesanan dengan menggunakan alat tulis pensil dan kertas menyebabkan terjadinya double order (redudansi) dan ketidak akuratan pemesanan dari pelanggan akibat tertumpuknya nota order yang sering terjadi disaat situasi pelanggan ramai. Hal tersebut juga merepotkan pelayan dalam merekap data pesanan yang nantinya dipindahkan lagi dalam bentuk laporan pemesanan. hal ini tentu dapat memperlambat dan menganggu kinerja suatu usaha kuliner, karena kurang efisien serta pada akhirnya akan mengganggu proses penyajian. Dari segi pelanggan dapat menyebabkan pelanggan menunggu terlalu lama akibat penyajian yang terganggu.

Frekuensi pelanggan di foodcourt RSKIA cukup tinggi sehingga diperlukan suatu sistem yang meningkatkan efektifitas dan efesiensi pemesanan makanan.

Mengingat terjadi suatu wabah virus Corona yang mengharuskan orang untuk menjaga jarak satu sama lain serta menghindari keramaian maka pembuatan aplikasi berbasis web dapat membantu untuk mengatasi permasalahan sistem informasi pemesanan makanan yang berjalan saat ini dan memfasilitasi pemesanan makanan yang menjaga jarak karena berbasis web untuk meminimalisir kasus corona (Kurnia, Tanuwijaya, \& Sagirani, n.d.).

Oleh karena itu, dalam penelitian ini akan dibuat perancangan sistem informasi pemesanan makanan dengan menggunakan pemodelan Unified Modeling Languange (UML) dan diimplementasikan dalam Bahasa pemograman PHP dengan framework codeigniter dan database My SQL.

Sistem informasi menurut (Listine, Nurhakim, Dwiatmoko, \& Excelsior, 2015) Sistem Informasi adalah kombinasi dari manusia, fasilitas atau alat teknologi, media, prosedur dan pengendalian yang bermaksud menata jaringan komunikasi yang penting, proses atas transaksi-transaksi tertentu dan rutin, membantu manajemen dan pemakai intern dan ekstern dan menyediakan dasar pengambilan keputusan yang tepat (Jogiyanto, 2005).

Menurut Kamus Besar Bahasa Indonesia (KBBI), arti kata pemesanan adalah proses, cara, perbuatan memesan atau memesankan. Pemesanan berasal dari kata dasar pesan. Pemesanan memiliki arti dalam kelas nomina atau kata benda sehingga pemesanan dapat menyatakan nama dari seseorang, tempat, atau semua benda dan segala yang dibendakan. 
Sistem informasi pemesanan makanan adalah sebuah program komputer bertujuan membantu manajemen foodcourt dalam kegiatan transaksi pemesanan makanan dan laporan-laporan yang diperlukan foodcourt (Putra, Rumanti, \& Athari, 2021). Kegiatan itu adalah mengolah data pelanggan, data makanan dan minuman, data transaksi pemesanan, dan laporan harian dan bulanan pemesanan.

\section{Metode Penelitian}

Dalam proses pengumpulan data, penulis menggunakan metode penelitian kualitatif dengan pendekatan deskriptif, dimana menurut (Sugiyono \& Kuantitatif, 20016), metode penelitian kualitatif adalah metode penelitian yang digunakan untuk penelitian pada kondisi objektif yang alamiah dimana peneliti adalah sebagai instrumen kunci, teknik penelitian data dilaksanakan secara gabungan, analisa data bersifat induktif, hasil penelitian lebih menekankan pada makna dari pada generalisasi. Dalam penelitian ini juga menggunakan metode penelitian deskriptif. Metode deskriptif adalah gambaran semua data yang kemudian dianalisis dan dibandingkan berdasarkan kenyataan yang sedang berlangsung dan mencoba untuk memberikan pemecahan selanjutnya (Ladjamudin, 2013).

Pada tahap perancangan, penulis menggunakan metode pengembangan prototype. Pada model prototype meliputi proses-proses yaitu pengumpulan kebutuhan, perancangan dan evaluasi prototype. Selain itu, sistem akan diuji menggunakan metode black box. Metode black box ini bertujuan untuk memeriksa program setelah selesai dirancang, guna untuk mengetahui aplikasi berfungsi dengan baik, dan bekerja secara efisien. Dengan menentukan tujuan dan kebutuhan yang diperlukan, kemudian membuat perancangan sistem pemesanan makanan yang dibangun agar dapat berjalan dengan baik pada tahap implementasi dan melakukan evaluasi prototype perancangan sistem informasi yang dibuat.

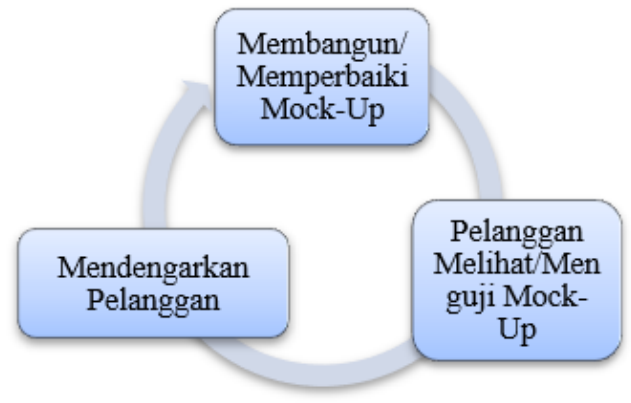

\section{Gambar 1. Ilustrasi Model Prototyping}

\section{Hasil dan Pembahasan}

Perancangan sistem ini dibuat sebagai tahapan untuk mempersiapkan proses implementasi dan untuk memberikan gambaran umum tentang sistem yang dikembangkan kepada penggunanya. Gambaran umum dari sistem yang diusulkan adalah untuk memberikan gambaran secara umum atau keseluruhan sistem kepada pemakai mengenai sistem informasi yang baru. 


\section{Perancangan Sistem Informasi}

\section{A. Diagram Use Case}

Use Case adalah suatu urutan interaksi yang saling berkaitan antara sistem dan actor (Kurniawan, 2018). Use case dijalankan melalui cara menggambarkan tipe interaksi antara user suatu program (sistem) dengan sistemnya sendiri. Diagram use case untuk aplikasi pemesanan makanan untuk admin dapat dilihat pada Gambar 2.

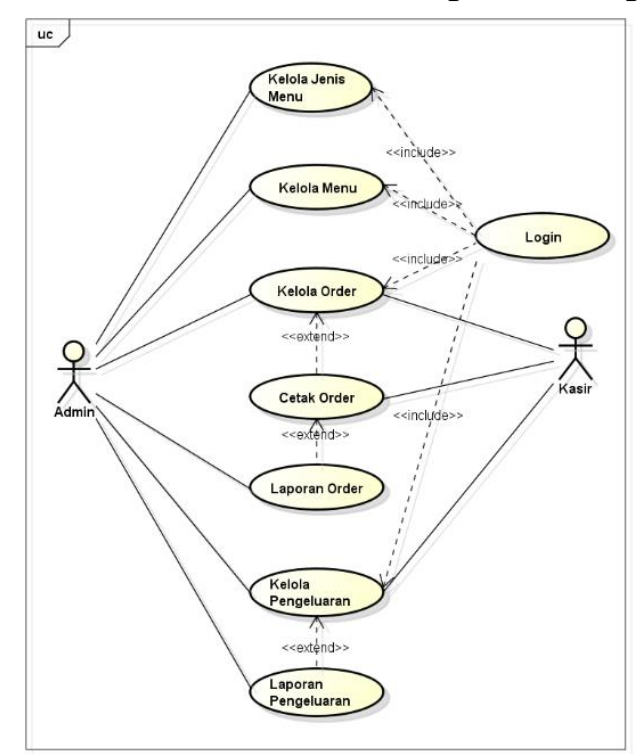

Gambar 2. Use Case Diagram Aplikasi Pemesanan Makanan

Terdapat dua jenis actor yaitu admin dan kasir. Admin mengelola jenis menu seperti makanan, minuman, snack dan dessert yang kemudian akan muncul sebagai pilihan di dalam proses kelola menu. Kemudian admin melakukan proses kelola order yang dapat langsung melakukan proses laporan order. Selanjutnya aktor admin melakukan proses kelola pengeluaran dan proses laporan pengeluaran. Kasir melakukan proses kelola order yang dapat langsung melakukan proses cetak order setelahnya.kemudian kasir juga dapat melakukan proses kelola pengeluaran.

\section{B. Diagram Activity}

Diagram aktivitas menggambarkan aliran kerja atau aktifitas dari sebuah sistem atau proses bisnis atau menu yang ada pada perangkat lunak. Diagram aktifitas menggambarkan aktifitas sistem bukan apa yang dilakukan oleh actor. Diagram aktivitas untuk aplikasi pemesanan makanan untuk admin dapat dilihat pada Gambar 3. 
Dinni Indriani, Asep Saeful

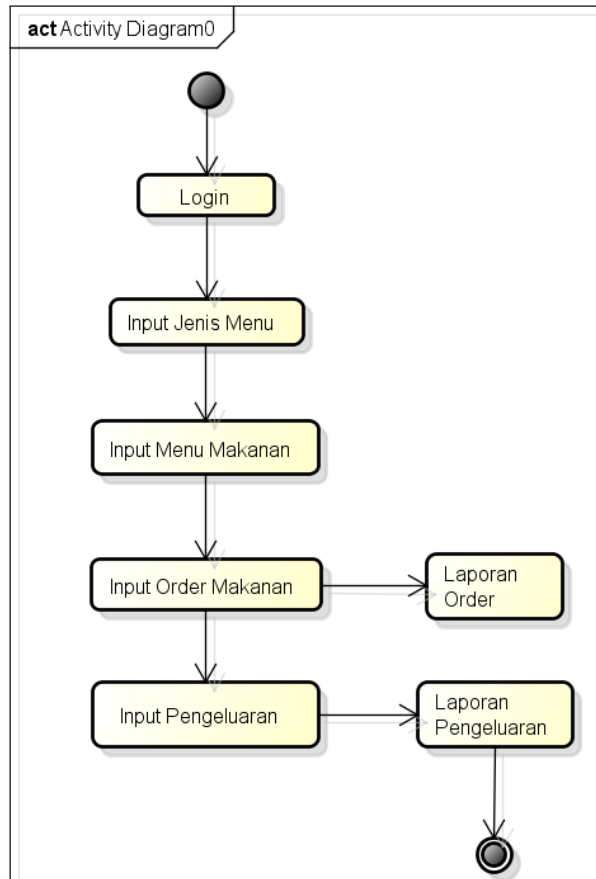

Gambar 3. Activity Diagram Aplikasi Pemesanan Makanan Admin

Terdapat tujuh aktivitas dari diagram aktivitas yang diusulkan yaitu dimulai dari aktivitas login, aktivitas memberikan input jenis makanan, input menu makanan, input order makanan yang dapat langsung melakukan aktivitas cetak laporan order, kemudian aktivitas input pengeluaran belanja yang dapat langsung melakukan aktivitas cetak laporan pengeluaran.

\section{Diagram Kelas}

Diagram kelas menjelaskan struktur sistem dari segi pendefinisian class-class yang akan dibuat untuk membangun sebuah sistem (Satzinger, Jackson, \& Burd, 2015). Diagram kelas untuk aplikasi pemesanan makanan untuk admin dapat dilihat pada Gambar 4.

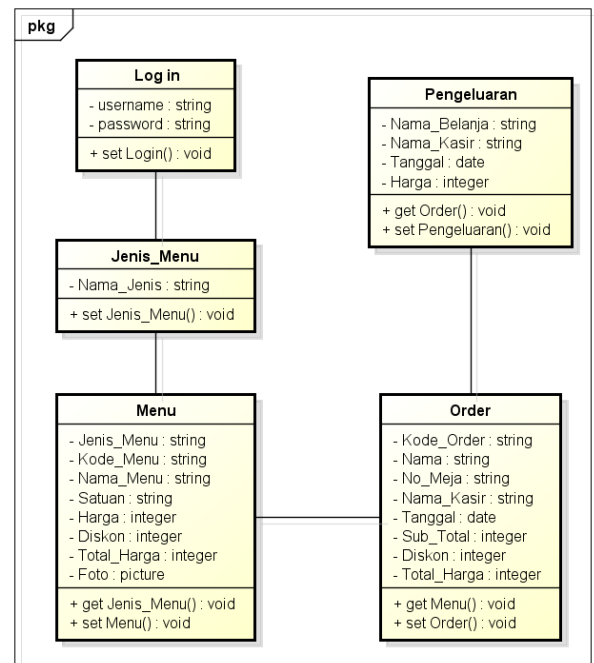

Gambar 4. Diagram Kelas Aplikasi Pemesanan Makanan 
Terdapat lima kelas yang terdiri dari kelas login, kelas jenis menu, kelas menu, kelas order, dan kelas pengeluaran. Kelas login memiliki atribut username dan password, kelas jenis menu memiliki atribut nama jenis menu, kelas menu memiliki atribut jenis menu, kode menu, nama menu, satuan, harga, diskon, total harga dan foto. Kelas order memiliki atribut kode order, nama, no meja, nama kasir, tanggal, sub total, diskon dan total harga dan kelas pengeluaran memiliki atribut nama belanja, nama kasir, tanggal dan harga.

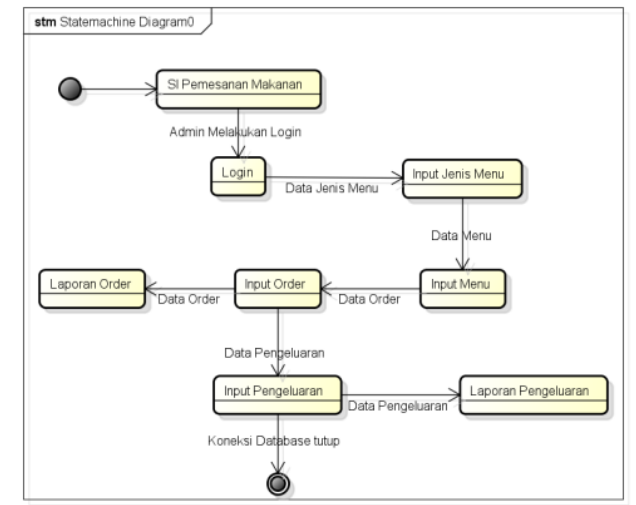

\section{Gambar 5. Statechart Aplikasi Pemesanan Makanan}

Terdapat tujuh state dari statechart yang diusulkan yaitu dimulai dari state login, state memberikan input jenis makanan, input menu makanan, input order makanan yang dapat langsung melakukan state cetak laporan order, kemudian state input pengeluaran belanja yang dapat langsung melakukan state cetak laporan pengeluaran.

\section{Implementasi Sistem Informasi}

\section{A. Tampilan Sistem Login}

Form login dibuat untuk memvalidasi user yang diberikan hak akses terhadap aplikasi pemesanan makanan di foodcourt RSKIA sesuai ditunjukkan pada gambar 6 sebagai berikut:

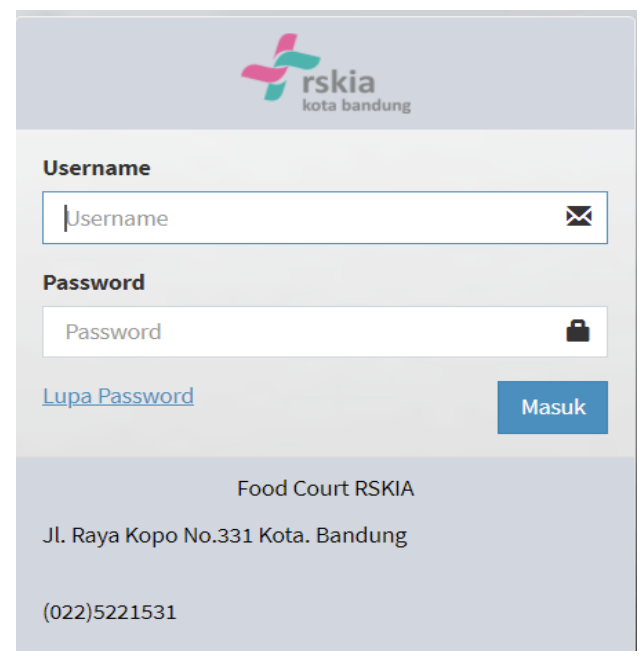

Gambar 6. Form Login 
Input dari Form Login yaitu username dan password yang dibuat dalam objek textbox. Admin untuk hak akses ke menu admin. Akun akan di validasi ketika button Login di click. Button batal untuk membatalkan yang sudah diinputkan dan button tutup untuk menutup aplikasi.

\section{B. Halaman Jenis Menu}

Form tambah jenis menu ditunjukan pada gambar 7 dan halaman tampilan jenis menu pada gambar 8 .

\section{Halaman Menu}

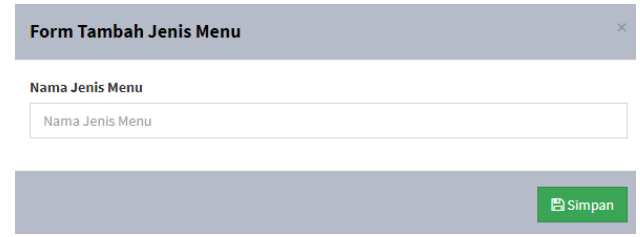

\section{Gambar 7. Form Tambah Jenis Menu}

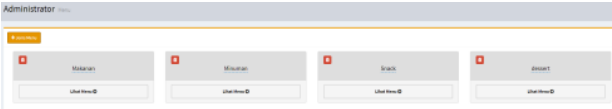

\section{Gambar 8. Tampilan Jenis Menu}

Form tambah menu ditunjukan pada gambar 9 dan halaman tampilan menu pada gambar 10.
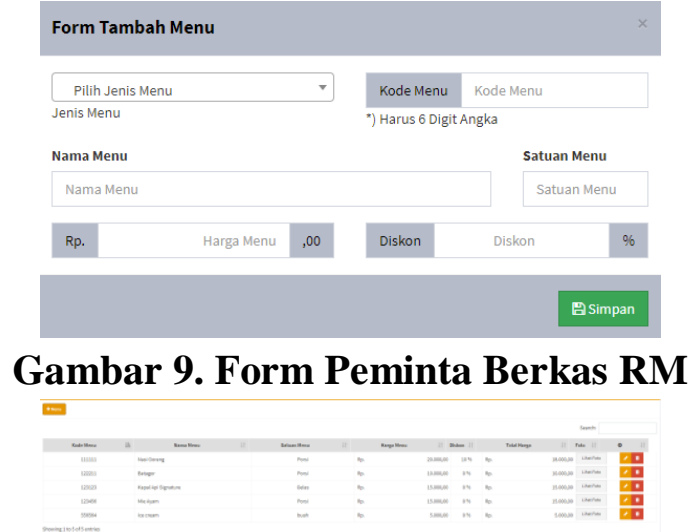

Gambar 10. Tampilan Menu

\section{Halaman Order}

Form tambah order ditunjukan pada gambar 11 dan halaman tampilan order pada gambar 12 .

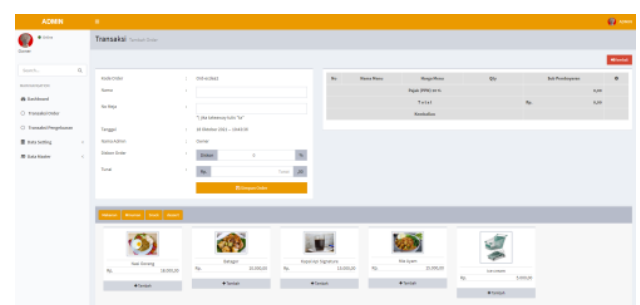

Gambar 11. Form Order

\section{E. Halaman Pengeluaran}


Form tambah pengeluaran ditunjukan pada gambar 13 dan halaman tampilan order pada gambar 14 .

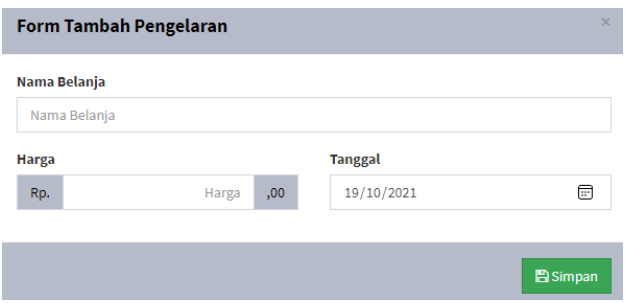

Gambar 13. Form Tambah Pengeluaran

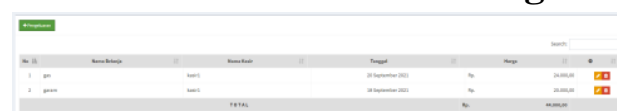

Gambar 14. Halaman Pengeluaran

\section{F. Laporan}

Laporan order dapat dilakukan sorting berdasarkan tanggal dan di cetak dalam bentuk file *csv, *xlxs, *pdf dan langsung cetak ke dalam printer yang ditunjukan pada gambar 15 .

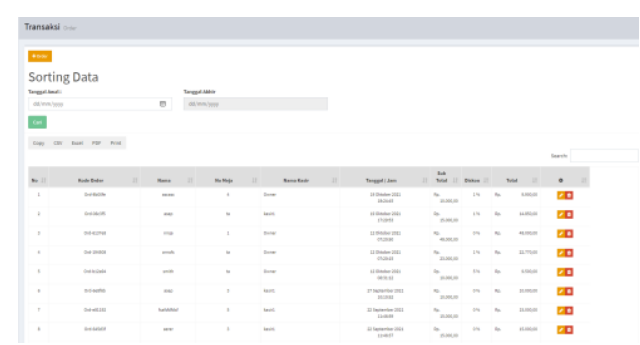

Gambar 15. Laporan Order

Tampilan cetak laporan order setelah dilakukan sorting dapat dilihat pada gambar 16.

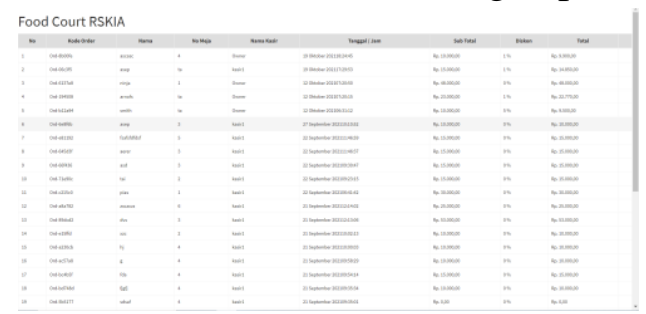

\section{Gambar 16. Cetak Laporan Order}

Laporan pengeluaran dapat dilakukan sorting berdasarkan tanggal dan di cetak dalam bentuk file *csv, *xlxs, *pdf dan langsung cetak ke dalam printer yang ditunjukan pada gambar 17 dan tampilan cetak laporan pengeluaran setelah dilakukan sorting dapat dilihat pada gambar 18 .

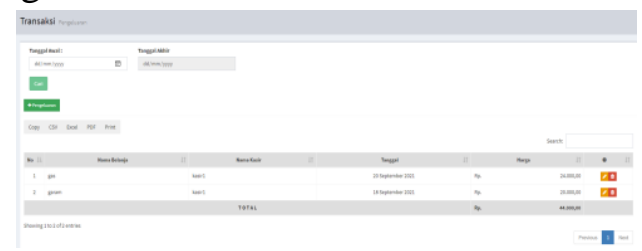

Gambar 17. Laporan Pengeluaran 


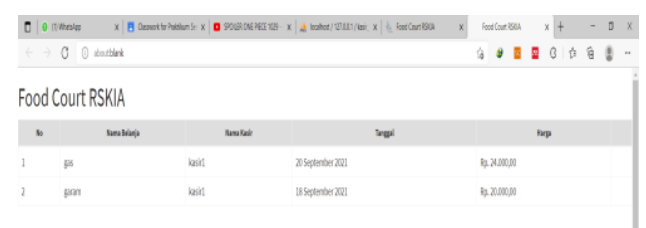

Gambar 18. Cetak Laporan Pengeluaran

\section{Spesifikasi Hardware dan Software}

\section{Perangkat Keras (Hardware)}

Untuk mendukung kinerja sistem informasi pemesanan makanan berbasis web dibutuhkan spesifikasi perangkat keras (Hardware) agar sistem berjalan dengan baik (Pasaribu \& Taryanto, 2018). Berikut adalah spesifikasi yang disarankan:

\begin{tabular}{|c|c|}
\hline Hardware & $\begin{array}{c}\text { Contoh } \\
\text { Hardware }\end{array}$ \\
\hline Processor & $\begin{array}{l}\text { Inter } \\
\text { Pentium } \\
\text { CPU Core i3 }\end{array}$ \\
\hline RAM & $\begin{array}{l}2 \text { GB atau } \\
\text { lebih tinggi }\end{array}$ \\
\hline Hardisk & $\begin{array}{l}320 \text { GB atau } \\
\text { lebih tinggi }\end{array}$ \\
\hline Keyboard & $\begin{array}{l}\text { Kompatible } \\
\text { dengan Ms. } \\
\text { Windows }\end{array}$ \\
\hline Mouse & $\begin{array}{l}\text { Kompatible } \\
\text { dengan Ms. } \\
\text { Windows }\end{array}$ \\
\hline
\end{tabular}

\section{Perangkat Lunak (Software)}

Dalam perancangan, sistem informasi pemesanan makanan berbasis web membutuhkan perangkat lunak (software) sebagai pendukung untuk kebutuhan program. Adapun spesifikasi perangkat lunak (software) untuk membangun sistem yang dirancang sebagai berikut:

Tabel 2 Spesifikasi Software

\begin{tabular}{ll}
\hline \multicolumn{1}{c}{ Hardware } & \multicolumn{1}{c}{ Contoh Hardware } \\
\hline Sistem Operasi & Ms Windows 7 atau lebih tinggi \\
\hline Pemograman & $P H P$ \\
\hline Pengolahan Database & $M y S Q L$ \\
\hline Web Server & XAMPP \\
\hline
\end{tabular}




\section{Kesimpulan}

Penelitian ini menghasilkan sebuah perancangan implementasi sistem pemesanan makanan berbasis web menggunakan bahasa pemograman PHP, framework codeigniter, dan database My SQL. Aplikasi ini terdiri dari halaman login, halaman jenis menu, halaman menu, halaman order dan halaman pengeluaran. Secara umum pengguna dari sistem aplikasi pemesanan makanan menggunakan web ini adalah admin dan kasir. Website ini dapat mempercepat pelayanan terhadap konsumen khususnya pada saat melakukan transaksi penjualan karena website ini dilengkapi dengan pemilihan makanan berupa gambar dan memuat harga dari setiap makanan serta ditunjang dengan tampilan yang user friendly.

Sistem yang dihasilkan dari penelitian ini masih berpotensi untuk dikembangkan lebih lanjut. Misalnya untuk penambahan fitur pembagian keuntungan manajemen food court dengan pengelola stand, fitur pembayaran dengan sistem deposit, dan lain-lain yang belum dibahas pada penelitian ini atau bahkan ke pengembangan sistem menjadi berbasis android. 


\section{Bibliografi}

Jogiyanto, H. M. (2005). Analisis dan Desain Sistem Informasi: Pendekatan Terstruktur. Andi, Yogyakarta.

Kurnia, Citra Indah, Tanuwijaya, Haryanto, \& Sagirani, Tri. (n.d.). Sistem Informasi Food Court Pada Pusat Perbelanjaan Smart Surabaya. Universitas Dinamika.

Kurniawan, Tri A. (2018). Pemodelan use case (UML): evaluasi terhadap beberapa kesalahan dalam praktik. J. Teknol. Inf. Dan Ilmu Komput, 5(1), 77.

Ladjamudin, Al Bahra Bin. (2013). Analisis dan Desain Sistem Informasi, Graha ilmu. Yogyakarta.

Listine, Ditta, Nurhakim, Nurhakim, Dwiatmoko, Marselinus Untung, \& Excelsior, T. P. (2015). Studi teknis penentuan geometri peledakan dan powder factor (pf) pada pembongkaran bijih besi di pt putera bara mitra, desa mentawakan mulya kec. Mantewe, kab. Tanah bumbu, kalimantan selatan. Jurnal Geosapta, 1(01).

Pasaribu, Johni S., \& Taryanto, Ardi. (2018). Implementasi Strategi E-Marketing Berbasis Web (Studi Kasus: Perusahaan Katering Dan Dekorasi). Jurnal E-Komtek (Elektro-Komputer-Teknik), 2(1), 10-22.

Putra, Hervin Tri, Rumanti, Agustina, \& Athari, Nurdhintya. (2021). Analisis Dan Perancangan Sistem Informasi Manajemen Pendukung Klinik Pratama Sahabat Ibu Dan Anak Jalan Siti Munigar Kota Bandung Dengan Menggunakan Metode Waterfall. EProceedings of Engineering, 8(2).

RRZ, Bambang Arief, Hudiaman, M., Wicaksana, Akbar Pangestu, \& Listiyani, Ninies. (2013). Kajian Bentuk Kursi pada Food Court di Kota Bandung. Reka Jiva, 1(01).

Satzinger, John W., Jackson, Robert B., \& Burd, Stephen D. (2015). Systems analysis and design in a changing world. Cengage learning.

Sugiyono, M. P. P., \& Kuantitatif, P. (20016). Kualitatif, dan R\&D, Bandung: Alfabeta. Cet. VII. 